\title{
UNDANG-UNDANG NOMOR 8 TAHUN 1999 TENTANG PERLINDUNGAN KONSUMEN DITINJAU DARI LAW AS AN ALLOCATIVE SYSTEM
}

\author{
Tri Setiady \\ Suhaendi Salidja \\ Universitas Wiralodra
}

Email: trisetiady@unwir.ac.id, suhaendisalidjaunwir@gmail.com

\begin{abstract}
Lawrence M. Friedman argues that the legal system is actually built by three components, namely legal substance, legal structure, and legal culture. The three components of the legal system are actually complementary and are in a functional relationship. To uphold the rule of law, the three components of the legal system must be developed simultaneously and integrally. Protection of consumers is seen materially and formally as being increasingly important, given the progress of science and technology which is the driving force for the productivity and efficiency of producers of goods or services that they produce in order to achieve business goals. In order to pursue and achieve these two things, finally either directly or indirectly, then consumers will generally feel the impact.
\end{abstract}

\section{Keywords: Consumer Protection, legal system, legal structure, and legal culture,}

\section{PENDAHULUAN}

Pembangunan hukum di Indonesia tahun 1970an tentu memiliki karakteristik, visi, misi yang berbeda dengan pembangunan hukum era reformasitahun 1998; begitu pula halnya pembangunan hukum dikedua era tersebut berbeda di tengah-tengah era globalisasi di segala bidang kehidpuan, baik bidang ekonomi, keuangan, perdagangan maupun di bidang hukum. Pembangunan hukum di era reformasi sampai saat ini tengah mengalmi tantangan perubahan, baik dalam negeri maupun hubungan internasional. Tantangan perubahan dalam sistem tatanegaraan Indonesia yang tengah mengalami masa transisi dari sistem otoritarian memasuki sistem demokrasi tidaklah cukup diatasi dengan melakukan perubahanperubahan, baik di bidang perundang-undangan, perekonomian, politik, melaikan harus diikuti dengan perubahan cara pandang dan sikap masyarakat dan birolrasi tentang baik buruknya atau kuat lemahnya sistem baru yang akan dianut bagi kepentingan masa depan bangsa Indonesia ${ }^{1}$.

\footnotetext{
${ }^{1}$ Romli Atmasasmita, Teori Hukum Intergratif (Rekontruksi Terhadap Teori Hukum Pembangunan dan Teori Hukum Progresif, Genta Publishing, Yogyakarta, 2012, hlm. 94-95.
} 


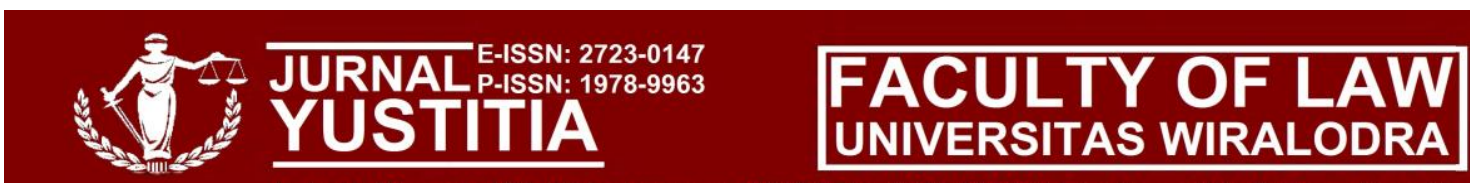

J. Ir. H. Djuanda KM. 03 Indramayu 45213 Telp. 0234-275599 Email: yustitia.fh@unwir.ac.id

Lawrence M. Friedman mengemukakan bahwa sistem hukum sesungguhnya dibangun oleh tiga komponen, yaitu substansi hukum (legal substance), struktur hukum (legal structure), dan budaya hukum (legal culture) $)^{2}$. Ketiga komponen sistem hukum tersebut sesungguhnya bersifat komplementer dan berada dalam suatu hubungan fungsional. Untuk menegakkan supremasi hukum, ketiga komponen sistem hukum tersebut harus dikembangkan secara simultan dan integral.

1. Struktur

Yang dimaksudkan dengan sistem hukum mempunyai struktur adalah kerangka atau rangkanya, bagian yang tetap bertahan, bagian yang memberi semacam bentuk dan batasan terhadap keseluruhan. Di dalam Sorjono Soekanto dikatakan bahwa komponen ini menunjuk adanya kelembagaan yang diciptakan oleh sistem hukum lembagalembaga mana mempunyai pelekatan, fungsi-fungsi tersendiri di dalam bekerjanya sistem hukum tersebut. Lembaga lembaga ini antara lain adalah Lembaga Kepolisian, Lembaga Kejaksaan, Lembaga Pengadilan dan Lembaga Kepengacaraan. Secara singkat dapat dikatakan bahwa komponen yang bersifat struktural ini memungkinkan masyarakat untuk mengharapkan bagaimana suatu sistem hukum itu seharusnya bekerja (law in the books) ${ }^{3}$.

2. Substansi

Yang dimaksud dengan substansi adalah aturan, norma, dan pola perilaku nyata manusia yang berada dalam sistem itu. Substansi juga berarti "produk" yang dihasilkan oleh orang yang berada di dalam sistem hukum itu, keputusan yang mereka keluarkan, aturan baru yang mereka susun ${ }^{4}$.

3. Budaya Hukum (Kultural)

Yang dimaksud dengan budaya hukum adalah sikap manusia terhadap hukum dan sistem hukum kepercayaan, nilai, pemikiran serta harapannya. Dengan kata lain, budaya hukum adalah suasana pikiran sosial dan kekuatan sosial yang menentukan bagaimana hukum digunakan, dihindari, atau disalahgunakan ${ }^{5}$. Di dalam Sorjono Soekanto dikatakan jika komponen yang bersifat struktural dapat diibaratkan sebagai

2 Lawrence M. Friedman, 2001, Hukum Amerika: Sebuah Pengantar (American Law: An Introduction), Penerjemah oleh Wishnu Basuki, PT. Tatanusa, Jakarta, hlm 7.

3 Lawrence M. Friedman dalam bukunya The Legal System: A Sociology Science Perspective, dalam Soerjono Soekanto, et. all, 1986, Kriminologi Suatu Pengantar, Jakarta, Ghalia Indonesia, hlm. 129.

4 Lawrence M. Friedman, 2001, op. Cit, hlm. 8.

5 Ibid 


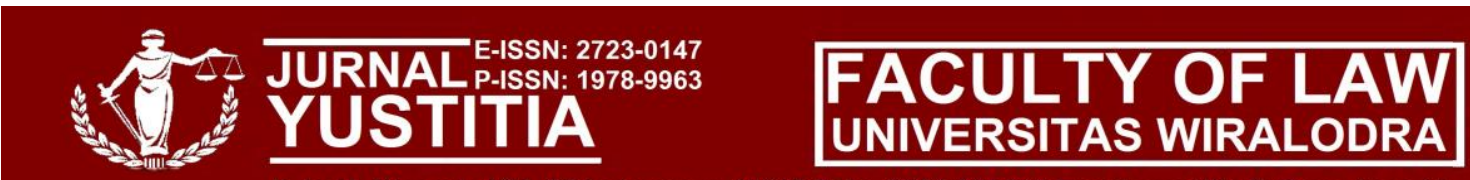

J. Ir. H. Djuanda KM. 03 Indramayu 45213 Telp. 0234-275599 Email: yustitia.fh@unwir.ac.id

suatu mesin, maka komponen kultural dapat diibaratkan sebagai bensin, yang merupakan penggerak dari mesin tadi. Dalam hal ini yang menjadi masalah adalah nilai dan sikap daripada fungsionaris yang bekerja dalam lingkungan pelaksanaan dan penegakan hukum. Komponen nilai dan sikap ini akan memberi pemahaman tentang bekerjanya suatu sistem hukum di dalam kenyataan (law in action) ${ }^{6}$.

Cara lain menggambarkan tiga unsur hukum tersebut di atas adalah dengan mengibaratkan struktur hukum seperti mesin. Substansinya adalah apa yang dihasilkan atau dikerjakan oleh mesin itu. Budaya hukum adalah apa saja atau siapa saja yang memutuskan untuk menghidupkan dan mematikan mesin itu serta memutuskan bagaimana mesin itu digunakan $^{7}$.

Upaya membentuk suatu produk hukum yang dapat diterima sebagai suatu norma, khususnya bagaimana suatu produk hukum menjamin hak asasi warga negara, harus memperhatikan tiga aspek penting yang berhubungan dengan pemberlakuan kaidah hukum tersebut, yaitu: ${ }^{8}$

1. Aspek Yuridis, artinya adalah bahwa penentuannya berdasarkan kaidah yang lebih tinggi tingkatannya (tidak boleh bertentangan dengan suatu produk hukum yang lebih tinggi tingkatannya) dan juga dibentuk menurut cara yang telah ditetapkan (misalnya di Indonesia suatu undang-undang dibentuk oleh Presiden dengan persetujuan DPR dan sebaliknya).

2. Aspek Sosiologis, artinya adalah efektivitas kaidah hukum dalam kehidupan bersama. Mengenai hal ini dikenal dua teori, yaitu;

a. Teori kekuasaan yang pokoknya menyatakan bahwa kaidah hukum mempunyai kekuatan sosiologis apabila dipaksakan berlakunya oleh penguasa, diterima ataupun tidak oleh warga masyarakat.

b. Teori pengakuan yang berpokok pangkal pada pendapat bahwa kelakuan kaidah hukum didasarkan pada penerimaan atau pengakuan masyarakat di mana kaidah hukum tersebut akan diberlakukan.

\footnotetext{
6 Sorjono Soekanto, op. cit., hlm. 129-130.

7 Lawrence M. Friedman, Loc cit., hlm. 8.

8 Purnadi Purbacaraka dan Soerjono Soekanto, 1993, Perihal Kaidah Hukum, Bandung, Citra Aditya Bakti, hlm. 88-92.
} 
3. Aspek Filosofis, artinya kaidah hukum tersebut sesuai dengan cita-cita hukum sebagai nilai positif tertinggi, misalnya Pancasila, masyarakat adil dan makmur, dan seterusnya.

Dengan demikian, ketiga macam cara berlaku tersebut, diharapkan kaidah yang tidak mati (dode regel), secara sosiologis maka hukum akan bersifat demokratis serta hukum secara filosofis maka hukum tersebut tidak hanya sebagai kaidah hukum yang hanya diharapkan atau dicita-citakan.

\section{IDENTIFIKASI MASALAH}

Berdasarkan hal-hal yang telah diuraikan diatas, maka permasalahan yang hendak dikemukakan dalam penulisan tesis ini adalah sebagai berikut dalam konteks hukum sebagai sistem alokasi yang disampaikan Friedman, kiranya hal ini juga perlu dilaksanakan di Indonesia. Peraturan perundang-undangan yang dihasilkan dalam segala bidang, apakah itu ekonomi, politik, sosial dan hankam perlu dikaji: how it performs?; how it treats people?; how it distribute?; dan how its cost and benefit? agar suatu peraturan perundang-undangan tersebut dapat diterapkan dan sesuai dengan tujuan dari pembuat peraturan perundangundangan tersebut. Dalam penulisan ini, akan dibahas mengenai Bagaimana UndangUndang Nomor 8 Tahun 1999 tentang Perlindungan Konsumen ditinjau dari konsep "Hukum sebagai Sistem Alokasi"?

\section{METODE}

Metode Pendekatan yang digunakan adalah yuridis normatif yaitu penelitian hukum yang mempergunakan sumber data sekunder ${ }^{9}$, dengan menyusun kerangka konsepsional, dengan merumuskan ketentuan yang terdapat dalam Peraturan Perundang-undangan yang menjadi dasar penelitian ${ }^{10}$. Spesifikasi Penelitian yang digunakan dalam Penelitian ini dilakukan secara deskriptif-analitis yaitu penelitian yang menggambarkan peristiwa yang sedang diteliti dan kemudian menganalisanya berdasarkan fakta-fakta berupa data sekunder yang diperoleh dari bahan hukum primer, bahan hukum sekunder dan bahan hukum tersier ${ }^{11}$. Penelitian ini dilakukan dalam dua tahap, yaitu penelitian kepustakaan (library research)

\footnotetext{
9 Ronny Hanitijo Soemitro, Metodologi Penelitian Hukum dan Jurimetri, Galia Indonesia, cet. ke-4, Jakarta, 1990, hlm. 30.

${ }^{10}$ Amirudin “et.al” Pengantar Metode Penelitian Hukum, Raja Grafindo Persada, Jakarta, 2000, hlm. 119.

${ }^{11}$ Soerjono Soekanto, Pengantar Penelitian Hukum, Grafindo, Jakarta, 2006, hlm. 10.
} 


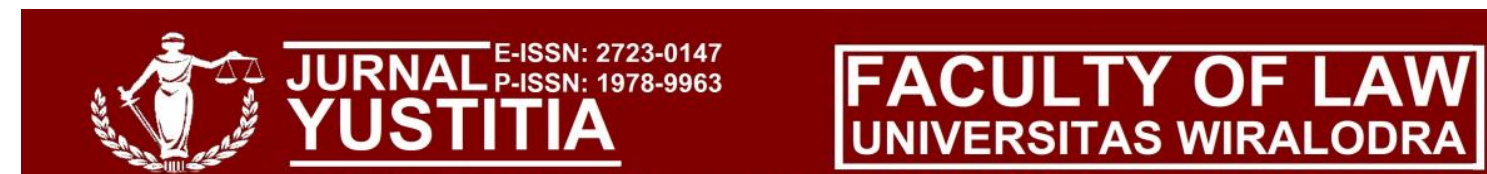

J. Ir. H. Djuanda KM. 03 Indramayu 45213 Telp. 0234-275599 Email: yustitia.fh@unwir.ac.id

dan pengumpulan data lapangan. Penelitian Kepustakaan (library research) digunakan untuk memperoleh data dalam penelitian ini yaitu: bahan hukum primer, bahan hukum sekunder dan bahan hukum tersier ${ }^{12}$. Metode analisis data yang digunakan dalam penelitian ini adalah metode analisis yuridis normatif kualitatif.

\section{IV.HASIL DAN PEMBAHASAN}

\section{A. Undang-Undang Nomor 8 Tahun 1999 tentang Perlindungan Konsumen ditinjau dari konsep "Hukum sebagai Sistem Alokasi"}

\section{How it Performs}

Pembangunan dan perkembangan perekonomian khususnya di bidang perindustrian dan perdagangan nasional telah menghasilkan berbagai variasi barang/jasa yang dapat dikonsumsi. Selain itu, globalisasi dan perdagangan bebas yang didukung oleh kemajuan teknologi telekomunikasi informatika telah memperluas ruang gerak arus transaksi barang dan /atau jasa yang ditawarkan bervariasi baik produksi dalam negeri maupun produksi dalam negeri ${ }^{13}$.

Kondisi yang demikian pada satu pihak mempunyai manfaat bagi konsumen karena kebutuhan konsumen akan barang dan/atau jasa yang diinginkan dapat terpenuhi serta semakin terbuka lebar kebebasan untuk memilih aneka jenis dan kuantitas barang dan/atau jasa sesuai dengan keinginan dan kemampuan konsumen ${ }^{14}$.

Di sisi lain, kondisi dan fenomena tersebut diatas dapat mengakibatkan kedudukan pelaku usaha dan konsumen menjadi tidak seimbang dan konsumen berada pada posisi yang lemah. Konsumen menjadi objek aktivitas bisnis untuk meraup keuntungan yang sebesarbesarnya oleh pelaku usaha melalui kiat promosi, cara penjualan, serta penerapan perjanjian standar yang merugikan konsumen. Faktor utama yang menjadi kelemahan konsumen adalah tingkat kesadaran konsumen akan haknya masih rendah. Hal ini terutama disebabkan oleh rendahnya pendidikan konsumen ${ }^{15}$.

Oleh karena itu, Undang-undang Perlindungan Konsumen dimaksudkan menjadi landasan hukum yang kuat bagi pemerintah dan lembaga konsumen swadaya mayarakat

\footnotetext{
${ }^{12}$ Sunaryati Hartono, "Kembali ke Metode Penelitian Hukum", dalam Bunga Rampai Metodologi Penelitian dan Penulisan Karya Ilmiah Hukum, Koko Kosidin (Ed), 1990, hlm. 4.

${ }^{13}$ Penjelasan Umun Undang-Undang Nomor 8 Tahun 1999 Tentang Perlindungan Konsumen

${ }^{14}$ Ibid

${ }^{15}$ Adrian Sutedi, Tanggung Jawab Produk Dalam Hukum Perlindungan Konsumen, Ghalia Indonesia, Bogor, 2006, hlm. 2.
} 


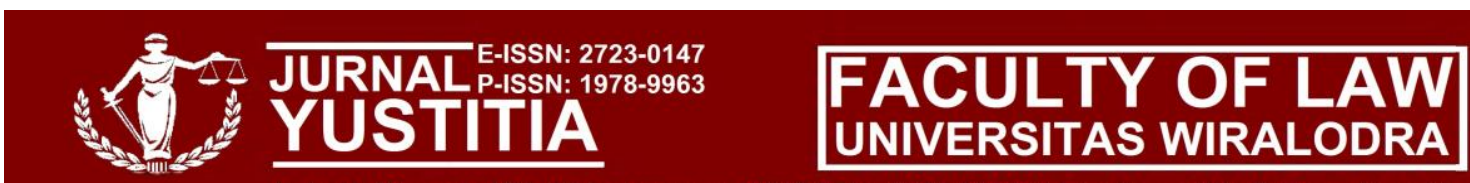

J. Ir. H. Djuanda KM. 03 Indramayu 45213 Telp. 0234-275599 Email: yustitia.fh@unwir.ac.id

untuk melakukan upaya pemberdayaan konsumen melalui pembinaan dan pendidikan konsumen. Upaya pemberdayaan penting karena tidak mudah menharapkan kesadaran pelaku usaha yang pada dasarnya prinsip ekonomi pelaku usaha adalah mendapat keuntungan yang semaksiamal mungkin dengan modal seminal mungkin. Prinsip ini sangat potensial merugikan kepentingan konsumen, baik secara langsung maupun tidak langsung ${ }^{16}$.

Ruang lingkup hukum perlindungan konsumen sulit dibatasi dengan menampungnya dalam satu jenis undang-undang, seperti Undang-Undang Perlindungan Konsumen. Hukum perlindungan konsumen selalu berhubungan dengan berbagai bidang dan cabang hukum itu senantiasa terdapat pihak yang berpredikat "konsumen"17. Istilah "hukum konsumen" dan "hukum perlindungan konsumen" sudah sering terdengar ${ }^{18}$. Namun, belum jelas benar apa saja yang termasuk ke dalam materi keduanya. Juga apakah keduanya "cabang" hukum itu identik. M.J. Leder menyatakan: In a sense there is no such creature as consumer law ${ }^{19}$. Sekalipun demikian, secara umum sebenarnya hukum konsumen dan hukum perlindungan konsumen itu seperti yang dinyatakan oleh Lowe yakni: rules of law which recognize the bargaining weakness of the individual consumer and which ensure that weakness is not unfairly exploted ${ }^{20}$.

Pakar masalah konsumen di Belanda Hondius menyimpulkan, para ahli hukum umumnya sepakat mengartikan konsumen sebagai, pemakai terakhir dari benda dan jasa (uitendelijke gebruiker van goederen en diesten) ${ }^{21}$. Para konsumen merupakan golongan yang rentan dieksploitasi oleh pelaku usaha. Karena posisi konsumen yang lemah maka ia harus dilindungi oleh hukum. Salah satu sifat, sekaligus tujuan hukum itu adalah memberikan perlindungan (pengayoman) kepada masyarakat ${ }^{22}$. Undang-Undang Nomor 8 Tahun 1999 tentang Perlindungan Konsumen merupakan seperangkat aturan hukum untuk

\footnotetext{
${ }^{16}$ Ibid,

${ }^{17}$ Shidarta, Hukum Perlindungan Konsumen Indonesia, Edisi Revisi, PT Grasindo, Jakarta, 2006, Hlm 1. Setiap manusai adalah konsemen, disadari atau tidak. Dalam perspektif yang lebih luas, bahkan ada anggapan bahwa kita adalah konsumen dari produk politik yang disebut "hukum". Penjelasan mengenai hal ini baca; Edmond Cahn, "Law in Consumer Perspective, "University of Pennyvania Law review, No.112 (1963): hlm. $1-27$.

${ }^{18}$ Shidarta, Ibid, hlm. 13.

${ }^{19}$ M.J Leder, Consumer Law (plymounth; Macdonald and Evans), 1980, hlm. 1.

${ }^{20}$ R. Lowe, Comercial Law, ed6 (London; Sweet and Maxwell, 1983), hlm. 23.

${ }^{21}$ Hondius, "Konsumentenrecht, "1976, dalam Mariam Darus Badrulzaman, Perlindungan terhadap Konsumen dilihat dari Sudut Perjanjian Baku (Standar), dalam BPHN, Siposium Aspek-Aspek Hukum Perlindungan Konsumen, Binacipta, Bandung, 1986, hlm. 57.

${ }^{22}$ Celina Tri Siwi Kristiyanti, Hukum Perlindungan Konsumen, Sinar Grafika, Jakarta, 2009, hlm. 13.
} 


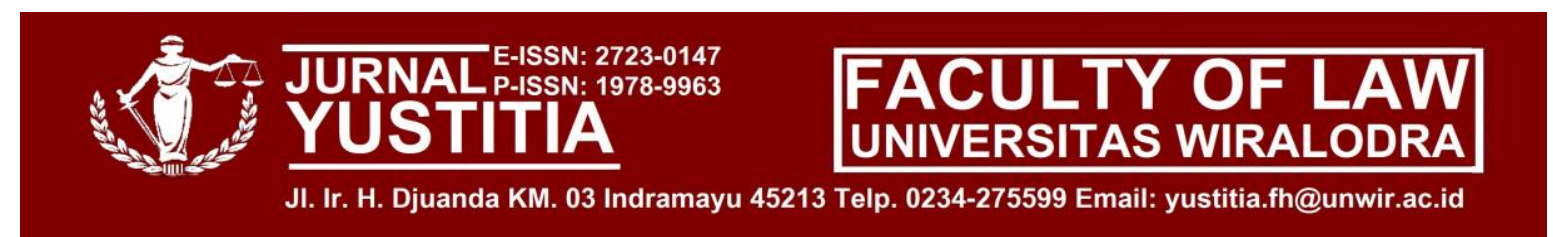

melindungi konsumen. Dalam Pasal 1 angka 1 Undang-Undang Nomor 8 Tahun 1999 tentang Perlindungan Konsumen Yang dimaksud Perlindungan Konsumen adalah :

"Perlindungan konsumen adalah segala upaya yang menjamin adanya kepastian hukum untuk memberi perlindungan kepada konsumen”.

\section{How it treats people}

Dalam setiap undang-undang yang dibuat pembentuk undang-undang, biasanya dikenal sejumlah asas atau prisip yang mendasari diterbitkannya undang $\neg$ undang tersebut. Asas-asas hukum merupakan fondasi suatu undang-undang dan peraturan pelaksananya ${ }^{23}$. Bila asas-asas dikesampingkan, maka runtuhlah bangunan undang-undang itu dan segenap peraturan pelaksanaannya ${ }^{24}$.

Sudikno Mertokusumo memberikan ulasan asas hukum sebagai berikut: bahwa asas hukum bukan merupakan hukum kongkrit, melainkan merupakan pikiran dasar yang umum dan abstrak, atau merupakan latar belakang peraturan yang kongkrit yang terdapat dalam dan di belakang setiap system hukum yang terjelma dalam peraturan perundang-undangan dan putusan hakim yang merupakan hukum positif dan dapat diketemukan dengan mencari sifat-sifat atau cirri-ciri yang umum dalam peraturan kongkrit tersebut ${ }^{25}$.

Sejalan dengan pendapat Sudikno tersebut, Satjipto Rahardjo berpendapat bahwa asas hukum bukan merupakan peraturan hukum, namun tidak hukum yang bisa dipahami tanpa mengetahui asas-asas hukum yang ada didalamnya, asas-asas hukum memberi makna etis kepada setiap peraturan-peraturan hukum serta tata hukum ${ }^{26}$. Asas hukum ini ibarat jantung peraturan hukum atas dasar dua alasan yaitu, pertama asas hukum merupakan landasan yang paling luas bagi lahirnya suatu peraturan hukum. Ini berarti bahwa penerapan peraturan-peraturan hukum itu dapat dikembalikan kepada asas-asas hukum. Kedua, karena asas hukum mengandung tuntutan etis, maka asas hukum diibaratkan sebagai jembatan antara peraturan $\neg$ peraturan hukum dengan cita-cita sosial dan pandangan etis masyarakatnya ${ }^{27}$.

Di dalam usaha memberikan perlindungan hukum terhadap konsumen, terdapat beberapa asas yang terkandung di dalamnya. Perlindungan konsumen dilakukan sebagai

\footnotetext{
${ }^{23}$ Abdoel Djamali, Pengantar Ilmu Hukum Indonesia, Raja Grafindo, Jakarta, 2006, hlm. 3.

${ }^{24}$ Yusuf Sofie, Pelaku Usaha, Konsumen dan Tindak Korporasi, Ghalia Indonesia, Jakarta, 2002, hlm. 25.

${ }^{25}$ Sudikno Mertokusumo, Penemuan Hukum : Suatu Pengantar, Liberty, Jakarta, 1996, hlm. 6.

${ }^{26}$ Satjipto Rahardjo, Ilmu Hukum, PT. Citra Aditya Bakti, Bandung, 1991, hlm. 87.

${ }^{27}$ Ibid, hlm. 85.
} 
bentuk usaha bersama antara masyarakat (konsumen), pelaku usaha dan Pemerintah sebagai pembentuk Peraturan Perundang-Undangan yang berkaitan dengan Perlindungan Konsumen, hal ini terkandung dalam ketentuan pasal 2 UUPK. Kelima asas tersebut adalah:

1) Asas manfaat

Asas manfaat dimaksudkan untuk mengamanatkan bahwa segala upaya dalam penyelenggaraan perlindungan konsumen harus memberikan manfaat sebesarbesarnya bagi kepentingan konsumen dan pelaku usaha secara keseluruhan. Asas ini menghendaki bahwa pengaturan dan penegakan hukum perlindungan konsumen tidak dimaksudkan untuk menempatkan salah satu pihak diatas pihak yang lain atau sebaliknya, tetapi adalah untuk memberikan kepada masing-masing pihak, pelaku usaha (produsen) dan konsumen, apa yang menjadi haknya. Dengan demikian, diharapkan bahwa pengaturan dan penegakan hukum perlindungan konsumen bermanfaat bagi seluruh lapisan masyarakat dan pada gilirannya bermanfaat bagi kehidupan berbangsa.

2) Asas keadilan

Asas keadilan dimaksudkan agar partisipasi seluruh rakyat dapat diwujudkan secara maksimal dan memberikan kesempatan kepada konsumen dan pelaku usaha untuk memperoleh haknya dan melaksanakan kewajibannya secara adil. Asas ini menghendaki bahwa pengaturan dan penegakan hukum perlindungan konsumen ini, konsumen dan pelaku usaha (produsen) dapat berlaku adil melalui perolehan hak dan penunaian kewajiban secara seimbang. Karena itu, UUPK mengatur sejumlah hak dan kewajiban konsumen dan pelaku usaha.

3) Asas keseimbangan

Asas keseimbangan dimaksudkan untuk memberikan keseimbangan antara kepentingan konsumen, pelaku usaha, dan pemerintah dalam arti materiil ataupun spiritual. Asas ini menghendaki agar konsumen, pelaku usaha (produsen), dan Pemerintah memperoleh manfaat yang seimbang dari pengaturan dan penegakan hukum perlindungan konsumen. Kepentingan antara konsumen, pelaku usaha (produsen) dan Pemerintah diatur dan harus diwujudkan secara seimbang sesuai dengan hak dan kewajibannya masing-masing dalam kehidupan berbangsa dan bernegara. Tidak ada salah satu pihak yang mendapat perlindungan atas 
kepentingannya yang lebih besar dari pihak lain sebagai komponen bangsa dan Negara.

4) Asas keamanan dan keselamatan konsumen

Asas ini dimaksudkan untuk memberikan jaminan atas keamanan dan keselamatan kepada konsumen dalam penggunaan, pemakaian dan pemanfaatan barang dan/atau jasa yang dikonsumsi atau digunakan. Asas ini menghendaki adanya jaminan hukum bahwa konsumen akan memperoleh manfaat dari produk yang dikonsumsi/dipakainya, dan sebaliknya bahwa produk itu tidak akan mengancam ketentraman dan keselamatan jiwa dan harta bendanya. Karena itu Undang-Undang ini membebankan sejumlah kewajiban yang harus dipenuhi dan menetapkan sejumlah larang yang harus dipatuhi oleh produsen dalam memperoduksi dan mengedarkan produknya.

5) Asas kepastian hukum

Asas ini dimaksudkan agar baik pelaku usaha maupun konsumen menaati hukum dan memperoleh keadilan dalam penyelenggaraan perlindungan konsumen, serta negara menjamin kepastian hukum. Artinya Undang-Undang ini mengharapkan bahwa aturan-aturan tentang hak dan kewajiban yang terkandung di dalam undang-undang ini harus diwujudkan dalam kehidupan sehari-hari sehingga masing-masing pihak memperoleh keadilan. Oleh karena itu, Negara bertugas dan menjamin terlaksananya undang-undang ini sesuai dengan bunyinya.

Memperhatikan substansi pasal 2 UUPK demikian pula penjelasannya, tampak bahwa perumusannya mengacu pada filosofi pembangunan nasional yaitu pembangunan manusia Indonesia seutuhnya yang berlandaskan pada falsafah Negara Republik Indonesia. Kelima asas yang disebutkan dalam pasal tersebut, bila diperhatikan substansinya, dapat dibagi menjadi 3 (tiga) asas yaitu:

1) Asas kemanfaatan yang didalamnya meliputi asas keamanan dan keselamatan konsumen,

2) Asas keadilan yang didalamnya meliputi asas keseimbangan, dan

3) Asas kepastian hukum.

Radbruch menyebutkan keadilan, kemanfaatan, dan kepastian sebagai "tiga ide dasar hukum" atau " tiga nilai dasar hukum", yang berarti dapat dipersamakan dengan asas hukum. 


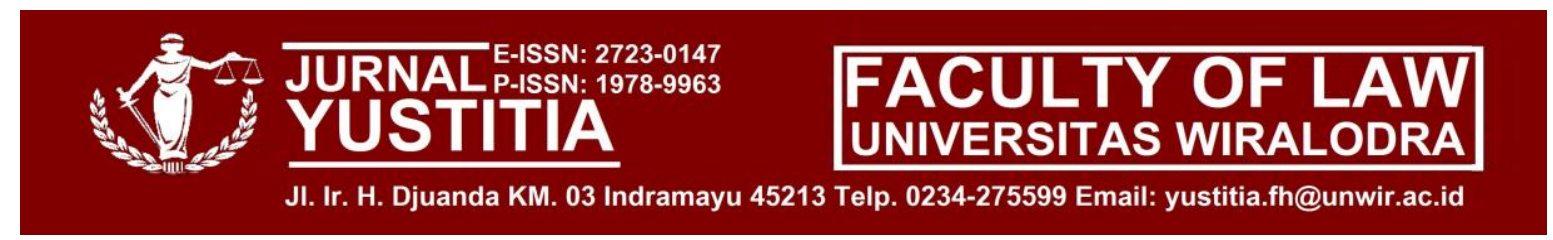

Keadilan, kemanfaatan, dan kepastian hukum juga oleh banyak jurist menyebut sebagai tujuan hukum. Asas keamanan dan keselamatan konsumen yang dikelompokkan ke dalam asas manfaat oleh karena keamanan dan keselamatan konsumen itu sendiri bagian dari manfaat penyelenggaraan perlindungan yang diberikan kepada konsumen disamping kepentingan pelaku usaha secara keseluruhan ${ }^{28}$.

Sedangkan asas keseimbangan dikelompokkan ke dalam asas keadilan, mengingat hakikat keseimbangan yang dimaksud adalah juga keadilan bagi kepentingan masing-masing pihak, yaitu konsumen, pelaku usaha, dan Pemerintah. Kepentingan Pemerintah dalam hubungan ini tidak dapat dilihat dalam hubungan transaksi dagang secara langsung menyertai pelaku usaha dan konsumen. Kepentingan Pemerintah dalam rangka mewakili kepentingan publik yang kehadirannya tidak secara langsung di antara para pihak tetapi melalui berbagai pembatasan dalam bentuk kebijakan yang dituangkan dalam berbagai peraturan perundang-undangan. Keseimbangan perlindungan antara pelaku usaha dan konsumen menampakkan fungsi hukum yang menurut Roscoe Pound sebagai sarana pengendalian hidup bermasyarakat dengan menyeimbangkan kepentingan-kepentingan yang ada dalam masyarakat atau dengan kata lain sebagai sarana kontrol sosial ${ }^{29}$.

Keseimbangan perlindungan hukum terhadap pelaku usaha dan konsumen tidak terlepas dari adanya pengaturan tentang hubungan-hubungan hukum yang terjadi antara para pihak. Menurut Bellefroid, secara umum hubungan-hubungan hukum yang bersifat publik maupun privat dilandaskan pada prinsip-prinsip atau asas kebebasan, persamaan dan solidaritas. Dengan prinsip atau asas kebebasan, subyek hukum bebas melakukan apa yang diinginkannya dengan dibatasi oleh keinginan orang lain dan memelihara akan ketertiban sosial.

Dengan prinsip atau asas kesamaan, setiap individu mempunyai kedudukan yang sama di dalam hukum untuk melaksanakan dan meneguhkan hak-haknya. Dalam hal ini hukum memberikan perlakuan yang sama terhadap individu. Sedangkan prinsip atau asas solidaritas sebenarnya merupakan sisi balik dari kebebasan. Apabila dalam prinsip atau asas kebebasan yang menonjol adalah hak, maka di dalam prinsip atau asas solidaritas yang menonjol adalah kewajiban, dan seakan-akan setiap individu sepakat untuk tetap

\footnotetext{
${ }^{28}$ Ahmadi Miru dan Sutarman Yodo, 2008, Hukum Perlindungan Konsumen, PT. Raja Grafindo Persada, Jakarta, hlm. 28.

${ }^{29}$ Ibid
} 


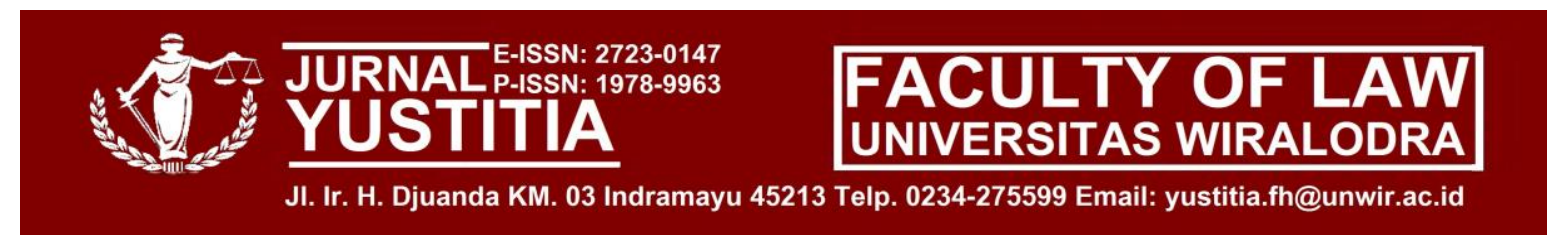

mempertahankan kehidupan bermasyarakat yang merupakan modus survival manusia. Melalui prinsip atau asas solidaritas dikembangkan kemungkinan Negara mencampuri urusan yang sebenarnya privat dengan alasan tetap terpeliharanya kehidupan berama. Dalam hubungan inilah kepentingan Pemerintah sebagaimana dimaksudkan dalam asas keseimbangan diatas yang sekaligus sebagai karakteristik dari apa yang dikenal dalam kajian hukum ekonomi.

Sejak masuknya paham welfare state, Negara telah ikut campur dalam perekonomian rakyatnya melalui berbagai kebijakan yang terwujud dalam bentuk peraturan perundangundangan, termasuk dalam hubungan kontraktual antara pelaku usaha dan konsumen. Pengaturan hal-hal tertentu yang berkaitan dengan masuknya paham Negara modern melalui welfare state, kita tidak menemukan lagi pengurusan kepentingan ekonomi oleh rakyat tanpa melibatkan Pemerintah sebagai lembaga eksekutif di dalam suatu Negara. Sesuai fungsi kehadiran Negara, maka Pemerintah sebagai lembaga eksekutif bertanggung jawab memajukan kesejahteraan rakyatnya yang diwujudkan dalam suatu pembangunan nasional. Campur tangan Pemerintah di Indonesia sendiri dapat diketahui dari isi Pembukaan dan pasal 33 Undang-Undang Dasar 1945, serta dalam GBHN dan dalam berbagai peraturan perundang-undangan yang menjadi aturan pelaksanaannya, termasuk Undang-Undang Perlindungan Konsumen. Dalam pasal 2 UUPK secara jelas dapat diketahui bahwa perlindungan secara jelas dapat diketahui bahwa perlindungan konsumen diselenggarakan dalam rangka pembangunan nasional, yang menjadi tanggung jawab Pemerintah.

Mengacu pada pasal 1 ayat 1 Undang-Undang No. 8 Tahun 1999 disebutkan bahwa perlindungan konsumen sebagai segala upaya yang menjamin adanya kepastian hukum untuk memberikan perlindungan kepada konsumen, Kata segala upaya adalah menyiratkan bahwa perlindungan konsumen bertujuan untuk membentengi tindakan sewenang-wenangan dan agar pihak pelaku usaha memberikan hak-hak yang dimiliki oleh konsumen sebagaimana mestinya. Agar segala upaya tersebut berjalan efektif, ukurannya secara kualitatif ditentukan dalam undang-undang perlindungan konsumen dan undang-undang lainnya juga dimaksudkan dan masih berlaku untuk memberikan perlindungan terhadap kepentingan konsumen, baik dalam hukum privat (perdata) maupun dalam bidang hukum public (hukum pidana maupun hukum administrasi negara).

Tujuan Perlindungan Konsumen, sebagaimana termaksud dalam ketentuan pasal 3 Undang-Undang Nomor 8 Tahun 1999 tentang Perlindungan Konsumen bertujuan: 
a. Meningkatkan kesadaran, kemampuan dan kemandirian konsumen untuk melindungi diri;

b. Mengangkat harkat dan martabat konsumen dengan cara menghindarkannya dari ekses negatif pemakaian barang dan/atau jasa;

c. Meningkatkan pemberdayaan konsumen dalam memilih, menentukan, dan menuntut hak-haknya sebagai konsumen;

d. Menciptakan sistem perlindungan konsumen yang mengandung unsur kepastian hukum dan keterbukaan informasi serta akses untuk mendapatkan informasi;

e. Menumbuhkan kesadaran pelaku usaha mengenai pentingnya perlindungan konsumen sehingga tumbuh sikap yang jujur dan bertanggungjawab dalam berusaha;

f. Meningkatkan kualitas barang dan/atau jasa yang menjamin kelangsungan usaha produksi barang dan/atau jasa, kesehatan, kenyamanan, keamanan, dan keselamatan konsumen.

Bahwa masing-masing undang-undang memiliki tujuan khusus. Hal itu tampak dalam pengaturan pasal 3 Undang-Undang No. 8 Tahun 1999 tentang perlindungan konsumen yang juga mengatur tujuan khusus perlindungan konsumen sekaligus membedakan tujuan umum ${ }^{30}$. Rumusan tujuan perlindungan konsumen huruf a dan e mencerminkan tujuan hukum mendapatkan keadilan. Sedangkan rumusan huruf a, b, termasuk $\mathrm{c}$ dan $\mathrm{d}$ serta huruf $\mathrm{f}$ mencerminkan tujuan hukum memberikan kemanfaatan, dan tujuan hukum khusus yang diarahkan untuk tujuan kepastian hukum tercermin dalam rumusan huruf $d$.

Pengelompokan ini tidak berlaku mutlak, oleh karena seperti yang dapat kita lihat dalam rumusan pada huruf a sampai dengan huruf $\mathrm{f}$ terdapat tujuan yang dapat dikualifikasi sebagai tujuan ganda. Kesulitan memenuhi ketiga tujuan hukum (umum) sekaligus sebagaimana dikemukakan sebelumnya, menjadikan sejumlah tujuan khusus dalam huruf a sampai dengan huruf $f$ dari pasal 3 tersebut hanya dapat tercapai secara maksimal, apabila didukung oleh keseluruhan subsistem perlindungan yang diatur dalam undang $\neg$ undang ini, tanpa mengabaikan fasilitas penunjang dan kondisi masyarakat. Unsur masyarakat sebagaimana dikemukakan berhubungan dengan persoalan kesadaran hukum dan ketaatan ${ }^{30}$ Achmad Ali, Menguak Takbir Hukum (Suatu Kajian Filosofis dan Sosiologis), Cetakan Kedua, PT. Toko
Gunung Agung Tbk, Jakarta, 2002, hlm. 25. 


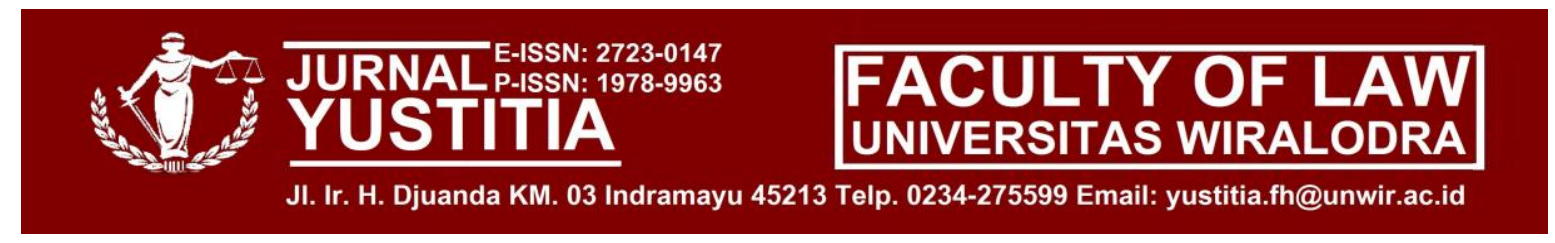

hukum, yang seterusnya menentukan efektivitas Undang-Undang Perlindungan Konsumen, bahwa kesadaran hukum, ketaatan hukum dan efektivitas perundang-undangan adalah tiga unsur yang saling berhubungan. ${ }^{31}$ Agar tujuan hukum perlindungan konsumen ini dapat berjalan sebagaimana seperti yang telah dicita-citakan, hal ini harus diperkuat oleh kesatuan dari keseluruhan sub sistem yang terkandung dalam undang-undang perlindungan konsumen didukung oleh sarana dan fasilitas yang menunjang.

\section{How it distribute}

Perlindungan konsumen sesungguhnya identik dengan perlindungan yang diberikan hokum. Oleh karena itu, perlindungan konsumen mengandung aspek hukum. Adapun materi yang mendapatkan perlindungan itu bukan sekedar fisik, melaikan terlebih-lebih hak-hak yang bersifat abstrak. Dengan kata lain perlindungan konsumen sesungguhnya identik dengan perlindungan yang diberikan hukum terhadap hak-hak konsumen.

Secara umum dikenal ada empat hak dasar konsumen, yaitu: ${ }^{32}$

1. Hak untuk mendapat keamanan (the right to safety);

2. Hak untuk mendapatkan informasi (the right to be informed);

3. Hak untuk memelih (the right to choose);

4. Hak untuk didengar (the right to he heard)

Empat hak dasar ini diakui secara internasioanl. Dalam perkembangannya, organisasi-organisasi konsumen yang tergabung dalam The International Organization of Consumers Union (IOCU) menambahkan lagi beberpa hak, seperti hak mendapatkan pendidikan konsumen, hak mendapat ganti kerugian, dan hak mendapatkan lingkungan hidup yang baik dan sehat ${ }^{33}$.

Ada delapan hak yang secara ekspisit dituangkan dalam pasal 4 UUPK, sementara satu hak terakhir dirumuskan secara terbuka. Hak-hak konsumen itu sebagai berikut:

1. Hak Konsumen Mendapatkan Keamanan

Konsumen berhak mendapatkan keamanan dan barang dan jasa yang ditawarkan kepadanya. Produk barang dan jasa itu tidak boleh membahayakan jika dikomsumsi sehingga konsumen tdk dirugikan baik secara jasmani dan rohani.

2. Hak mendapatkan Informasi yang benar

\footnotetext{
${ }^{31}$ Achmad Ali, Menjelajahi Kajian Empiris Terhadap Hukum, Yarsif Watampone, Jakarta, 1988, hlm. 191.

${ }^{32}$ Shidarta, Op Cit, hlm. 20.

${ }^{33}$ IOCU, Gerakan dan Langkah yayasan Lembaga Konsumen, Gunung Agung, Jakarta, 1982, hlm. 20.
} 
Setiap produk yang diperlkenalkan kedapa konsumen harus disertai informasi yang benar. Informasi yang di perlukan agar konsumen mempunyai gambaran yang keliru atas produk barang dan jasa. Informasi ini dapat disampaikan dengan berbagai cara seperti secara lisan kepada konsumen, melalui iklan di berbagai media atau mencantumkan dalam kemasaan produk.

3. Hak Untuk didengar

Hak yang erat kaitannya dengan hak untuk mendapatkan informasi adalah hak untuk didengar. Ini disebabkan informasi yang diberikan pihak yg berkepentingan atau berkompeten sering tidak cukup memuaskan konsumen. Untuk itu konsumen berhak mengajukan permintaan lebih lanjut.

4. Hak untuk memilih

Dalam mengkonsumsi suatu produk konsumen berhak menentukan pilihannya. Ia tidak boleh mendapatkan tekanan dari pihak luar sehingga ia tidak lagi bebas untuk membeli atau tidak membeli. Seandainya ia memebli ia juga bebas menentukan produk mana yang akan dibeli.

5. Hak untuk mendapatkan produk barang/jasa sesuai dengan nilai ukuran yang diberikan

Dengan hak ini berarti konsuemn harus dilindungi dari permainan harga yang tidak wajar. Dengan kata lain kuantitas dan kualitas barang/jasa yang dikonsumsi harus sesuai dengan nilai uang dibayar sebagai penggantinya.

6. Hak untuk mendapatkan ganti kerugian

Jika konsumen merasakankuantitas dan kualitas barang/jasa yang dikonsumensinya tidak sesuai dengan nilai tukar yang diberikannya, ia berhak mendapatkan ganti kerugian yang pantas. Jenis dan jumlah kerugian itu tentu saja harus sesuai dengan ketentuan yang berlaku atau atas kesepakatan masing-masing pihak.

7. Hak untuk mendapatkan penyelesaian hukum

Jika permintaan yang diajukan konsumen dirasakan tidak mendapatkan tanggapan yang layak dari pihak-pihak terkait (produsen) dalam hubungan hukum dengannya, maka konsumen berhak mendapatkan penyelesaian hukum, termasuk advokasi. Dengan kata lain konsumen berhak menuntut pertanggung jawaban pihak-pihak yang dipandang merugikan karena mengkonsumsi produk itu. 
8. Hak untuk mendapatkan lingkungan hidup yang baik dan sehat

Hak konsumen atas lingkungan yang baik dan sehat merupakaan hak yang diterima sebagai salah satuhak dasar konsumen oleh berbagai organisasi konsumen di dunia. Lingkungan hidup yang baik dan sehat berati sangat luas dan setiap makhlik hidup adalah konsumen atas lingkungan hidupnya.

9. Hak untuk dilindungi dari akibat negatif persaingan curang

Contoh bentuk yang sering terjadi dalam persaiangan curang adalah praktik banting harga (dumping). Satu produsen yang kuat mencoba mendesak produsen saingannya yang lebih lemah dengancar amnurunkan harga jual dibawah ongkos produksi. Tujuannya untik merebut pasar dan akhirnya produsen sainggannya berhenti produksi.

10. Hak untuk mendapatkan pendidikan konsumen

Masalah perlindungan konsumen di Indonesia termasuk masalah yang beru. Oleh karena itu, wajar bila masih banyak konsumen yang belum neyadari hak-hanknya. Kesadaran akan hak tidak dapat dipungkiri sejalan dengan kesadaran hukum. Makin tinggi tingkat kesadaran hukum masyarakat, makin tinggi penghormatannya pada hak-hak dirinya dan orang lain. Uapaya pendidikan konsumen tidak selalu harus melewati jenjang pendidikan formal tetapi dapat melalui media massa dan kegiatan lemabga swadaya masyarakat.

Lawan dari hak adalah kewajiban. Mengenai kewajiban konsumen dijelaskan dalam pasal 5 UUPK, yakni:

a. membaca atau mengikuti petunjuk informasi dan prosedur pemakaian atau pemanfaatan barang dan/atau jasa, demi keamanan dan keselamatan;

b. beritikad baik dalam melakukan transaksi pembelian barang dan/atau jasa;

c. membayar sesuai dengan nilai tukar yang disepakati;

d. mengikuti upaya penyelesaian hukum sengketa perlindungan konsumen secara patut.

Hak dan Kewajiban Pelaku Usaha

Dalam perdagangan pelaku usaha memiliki hak-hak yang harus diberikan dan dihormati oleh pihak-pihak lain dalam perdagangan tersebut, misalnya konsumen. Hak tersebut diimbangi dengan dibebankannya kewajiban pada pelaku usaha yang harus ditaati 


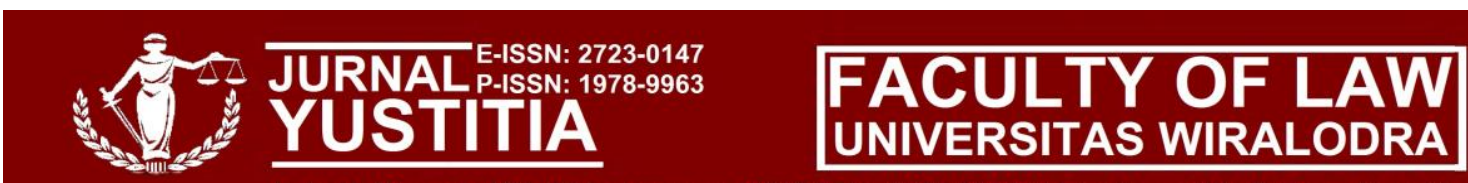

J. Ir. H. Djuanda KM. 03 Indramayu 45213 Telp. 0234-275599 Email: yustitia.fh@unwir.ac.id

dan dilaksanakan. Dalam pelaksanaannya antara hak dan kewajiban tersebut adalah seimbang.

Adapun hak pelaku usaha sebagaimana disebutkan dalam pasal 6 UUPK adalah :

a. hak untuk menerima pembayaran yang sesuai dengan kesepakatan mengenai kondisi dan nilai tukar barang dan/atau jasa yang diperdagangkan;

b. hak untuk mendapat perlindungan hukum dari tindakan konsumen yang beritikad tidak baik;

c. hak untuk melakukan pembelaan diri sepatutnya di dalam penyelesaian hukum sengketa konsumen;

d. hak untuk rehabilitasi nama baik apabila terbukti secara hukum bahwa kerugian konsumen tidak diakibatkan oleh barang dan/atau jasa yang diperdagangkan;

e. hak-hak yang diatur dalam ketentuan peraturan perundang-undangan lainnya.

Adapun kewajiban pelaku usaha diatur dalam pasal 7, yakni:

a. beritikad baik dalam melakukan kegiatan usahanya;

b. memberikan informasi yang benar, jelas dan jujur mengenai kondisi dan jaminan barang dan/atau jasa serta memberi penjelasan penggunaan, perbaikan dan pemeliharaan;

c. memperlakukan atau melayani konsumen secara benar dan jujur serta tidak diskriminatif;

d. menjamin mutu barang dan/atau jasa yang diproduksi dan/atau diperdagangkan berdasarkan ketentuan standar mutu barang dan/atau jasa yang berlaku;

e. memberi kesempatan kepada konsumen untuk menguji, dan/atau mencoba barang dan/atau jasa tertentu serta memberi jaminan dan/atau garansi atas barang yang dibuat dan/atau yang diperdagangkan;

f. memberi kompensasi, ganti rugi dan/atau penggantian atas kerugian akibat penggunaan, pemakaian dan pemanfaatan barang dan/atau jasa yang diperdagangkan;

g. memberi kompensasi, ganti rugi dan/atau penggantian apabila barang dan/atau jasa yang diterima atau dimanfaatkan tidak sesuai dengan perjanjian.

Piranti hukum yang melindungi konsumen tidak dimaksudkan untuk mematikan usaha pelaku usaha, tetapi justru sebaliknya perlindungan konsumen dapat mendorong iklim 


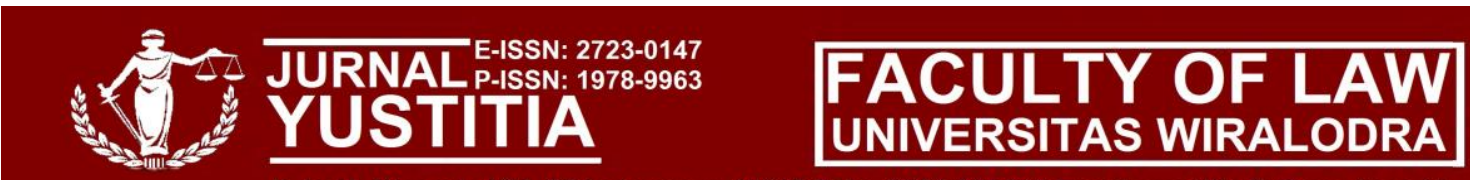

J. Ir. H. Djuanda KM. 03 Indramayu 45213 Telp. 0234-275599 Email: yustitia.fh@unwir.ac.id

berusaha yang sehat yang mendorong lahirnya perusahaan yang tangguh dalam menghadapi persaingan melalui penyediaan barang dan/atau jasa yang berkualitas.

Oleh karena itu dalam ketentuan Bab IV UUPK pasal 8 sampai dengan 17 menyebutkan perbuatan yang dilarang bagi pelaku usaha. Pada hakikatnya, laranganlarangan terhadap pelaku usaha tersebut adalah mengupayakan agar barang dan/atau jasa yang beredar di masyarakat merupakan produk yang layak edar, yang menyangkut asal-usul, kualitas sesuai dengan informasi pengusaha baik melalui label, iklan, dan lain sebagainya. ${ }^{34}$

Tujuan pengaturan ini menurut Nurmandjito adalah untuk mengupayakan terciptanya tertib perdagangan dalam rangka menciptakan iklim usaha yang sehat. Hal ini sebagai salah satu bentuk perlindungan konsumen, larangan-larangan tersebut dibuat berupaya untuk memastikan bahwa produk yang diproduksi produsen aman, layak konsumsi bagi konsumen.

Dalam ketentuan pasal 8 UUPK, disebutkan larangan-larangan tentang produksi barang dan/atau jasa, dan larangan memperdagangkan barang dan/atau jasa, antara lain:

1) Pelaku usaha dilarang memproduksi dan/atau memperdagangkan barang dan/atau jasa yang :

a. tidak memenuhi atau tidak sesuai dengan standar yang dipersyaratkan dan ketentuan peraturan perundang-undangan;

b. tidak sesuai dengan berat bersih, isi bersih atau netto, dan jumlah dalam hitungan sebagaimana yang dinyatakan dalam label atau etiket barang tersebut;

c. tidak sesuai dengan ukuran, takaran, timbangan dan jumlah dalam hitungan menurut ukuran yang sebenarnya;

d. tidak sesuai dengan kondisi, jaminan, keistimewaan atau kemanjuran sebagaimana dinyatakan dalam label, etiket atau keterangan barang dan/atau jasa tersebut;

\footnotetext{
${ }^{34}$ Nurmandjito, 2000, Kesiapan Perangkat Peraturan Perundang-Undangan Tentang Perlindungan Konsumen di Indonesia, "dalam Husni Syawali dan Neni Sri Imaniyati, penyunting", Hukum Perlindungan Konsmen, Mandar Maju, Bandung, hlm. 18.
} 
e. tidak sesuai dengan mutu, tingkatan, komposisi, proses pengolahan, gaya, mode, atau penggunaan tertentu sebagaimana dinyatakan dalam label atau keterangan barang dan/atau jasa tersebut;

f. tidak sesuai dengan janji yang dinyatakan dalam label, etiket, keterangan, iklan atau promosi penjualan barang dan/atau jasa tersebut;

g. tidak mencantumkan tanggal kadaluwarsa atau jangka waktu penggunaan/pemanfaatan yang paling baik atas barang tertentu;

h. tidak mengikuti ketentuan berproduksi secara halal, sebagaimana pernyataan "halal" yang dicantumkan dalam label;

i. tidak memasang label atau membuat penjelasan barang yang memuat nama barang, ukuran, berat/isi bersih atau netto, komposisi, aturan pakai, tanggal pembuatan, akibat sampingan, nama dan alamat pelaku usaha serta keterangan lain untuk penggunaan yang menurut ketentuan harus di pasang/dibuat;

j. tidak mencantumkan informasi dan/atau petunjuk penggunaan barang dalam bahasa Indonesia sesuai dengan ketentuan perundang-undangan yang berlaku.

2) Pelaku usaha dilarang memperdagangkan barang yang rusak, cacat atau bekas, dan tercemar tanpa memberikan informasi secara lengkap dan benar atas barang dimaksud.

3) Pelaku usaha dilarang memperdagangkan sediaan farmasi dan pangan yang rusak, cacat atau bekas dan tercemar, dengan atau tanpa memberikan informasi secara lengkap dan benar.

4) Pelaku usaha yang melakukan pelanggaran pada ayat (1) dan ayat (2) dilarang memperdagangkan barang dan/atau jasa tersebut serta wajib menariknya dari peredaran.

\section{How its Cost and Benefit}

Pandangan Roscou Pound tentang teori social interest yang merupakan embrio konsep "law as social engineering" yang disampaikan pada Konferensi "American Society of Sociology of Law" (1971) yang menyatakan "Looked at functionally, the law is an attempt to reconcile, to harmonise, to compromise these overlapping or complicating interest, ... so as to give effect to the greatest number of interests that weigh most in our civilization, with 


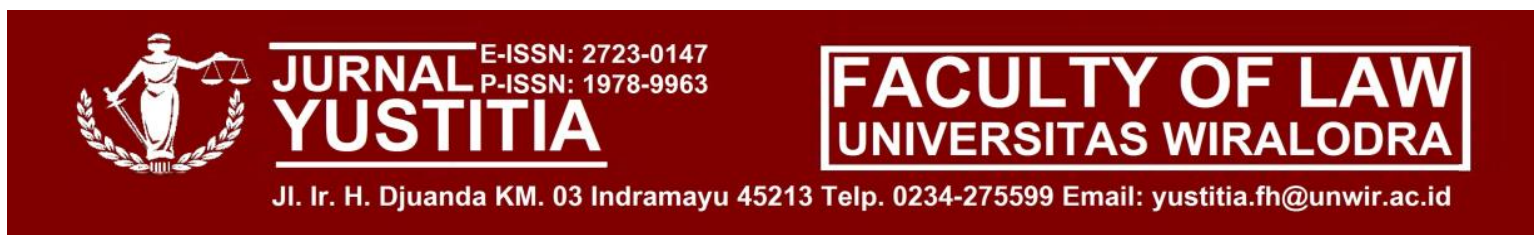

the least sacrifice of other interests..I venture to think of problems of eliminating friction and preculading waste in human enjoyment of the goods of existence, and of the legal order as system of social engineering whereby these ends are achieved". Pernyataan Pound ini menyatakan fungsi hukum sangat luas termasuk untuk rekonsiliasi, harmonisasi dan kompromi atas seluruh konflik kepentingan dalam masyarakat (individu, publik dan Negara), dengan prinsip hanya untuk kepentingan yang terbanyak dengan pengorbanan sekecil-kecilnya untuk kepentingan orang lain; itulah yang ia sebut law as social engineering atau a system of social engineering. Berdasarkan pernyataan Pound tersebut semakin jelas bahwa, konsep hukum yang dimaksud olehnya, adalah konsep hukum masa depan yang memiliki visi yang jelas tentang bagaimana menyelesaikan berbagai konflik kepentingan dalam kehidupan masyarakat dan hubungannya dengan peranan Negara dan individu. Pernyataan Pound ini ditafsirkan oleh Mochtar Kusumaatmadja dalam konteks pembangunan hukum nasional di Indonesia yang intinya bagaimana memerankan hukum sebagai sarana pembaruan masyarakat ${ }^{35}$.

Pendapat Pound kemudian mendorong perkembangan analisis non hukum terhadap perkembangan hukum. Tokoh analisis ilmu ekonomi terhadap hukum adalah Richard Posner, yang menggunakan pendekatan ilmu ekonomi berbasis tiga prinsip yaitu nilai, kemanfaatan dan efisiensi (value, utility, and efficiency). Analisis ekonomi Posner kemudian dikembangkan oleh Robert Cooter dan Thomas Ullen, dengan prinsip maksimalisasi, keseimbangan dan efisiensi (maximalization, equilibrium, and efficiency) terhadap hukum ${ }^{36}$.

Menurut Prof Romli Atmasasmita, beliau menyatakan meragukan pembentuk undang-undang di Indonesia memperhatikan pentingnya analisis non hukum karena hampir sebagian terbesar produk undang-undang di Indonesia memuat ketentuan sanksi pidana di dalamnya yang sering kontra produktif dan tidak berhasil mencapai tujuan awal dari pembentukan undang-undang tersebut ${ }^{37}$. Salah satu contohnya adalah Undang-Undang Perlindungan Konsumen. Untuk menganalisis Cost and Benefits dari Undang-Undang Perlindungan Konsumen akan digunakan teori Economic Analysis of Law dari Posner. Richard Posner menggunakan pendekatan ilmu ekonomi berbasis tiga prinsip yaitu value, utility and efficiency terhadap hukum ${ }^{38}$.

\footnotetext{
${ }^{35}$ Romli Atmasasmita, Op Cit, hlm. 40.

${ }^{36}$ Ibid, hlm. 42.

${ }^{37}$ Ibid

${ }^{38}$ Richard A Posner, Economic Analysis of Law, Edisi Keempat, Little Brown and Company, 1992.
} 


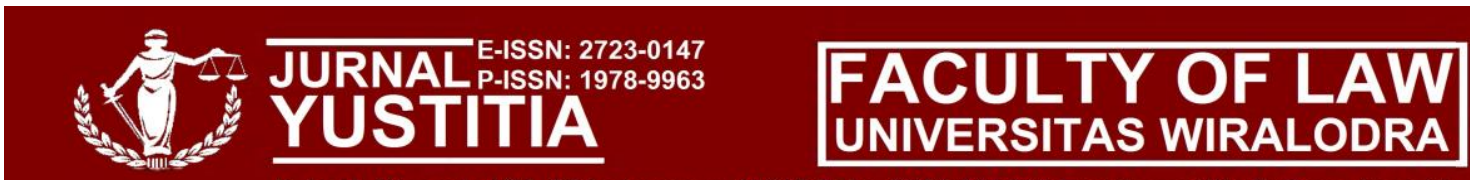

J. Ir. H. Djuanda KM. 03 Indramayu 45213 Telp. 0234-275599 Email: yustitia.fh@unwir.ac.id

Setiap orang, pada suatu waktu, dalam posisi tunggal/sendiri maupun berkelompok bersama orang lain, dalam keadaan apapun pasti menjadi konsumen untuk suatu produk barang atau jasa tertentu. Keadaan yang universal ini pada beberapa sisi menunjukkan adanya berbagai kelemahan pada konsumen sehingga konsumen tidak mempunyai kedudukan yang $\operatorname{aman}^{39}$.

Posisi konsumen sebagai pihak yang lemah juga diakui secara internasional sebagaimana tercermin dalam Resolusi Majelis Umum PBB No.A/RES/39/248 Tahun 1985, tentang Guidelines for Consumer Protection, yang menyatakan bahwa:40

"Taking into account the interest and needs of consumers in all countries, particularly those in developing countries, recognizing that consumers often face imbalance in economic terms, educational levels, and bargaining power, and bearing in mind that consumers should have the right of access to nonhazard-ous products, as well as the right to promote just, equitable and sustainable economic and social development".

Oleh karena itu secara mendasar konsumen juga membutuhkan perlindungan hukum yang sifatnya universal juga. Mengingat lemahnya kedudukan konsumen pada umumnya dibandingkan dengan kedudukan produsen yang lebih kuat dalam banyak hal, maka pembahasan perlindungan konsumen akan selalu terasa aktual dan selalu penting untuk dikaji ${ }^{41}$.

Perlindungan terhadap konsumen dipandang secara materiil maupun formal makin terasa sangat penting, mengingat makin majunya ilmu pengetahuan dan teknologi yang merupakan motor penggerak bagi produktifitas dan efisiensi produsen atas barang atau jasa yang dihasilkannya dalam rangka mencapai sasaran usaha. Dalam rangka mengejar dan mencapai kedua hal tersebut, akhirnya baik langsung atau tidak langsung, maka konsumenlah yang pada umumnya akan merasakan dampaknya ${ }^{42}$. Dengan demikian, upaya untuk memberikan perlindungan yang memadai terhadap kepentingan konsumen

\footnotetext{
${ }^{39}$ Husni Syawali \& Neni Sri Imaniyati, Hukum Perlindungan Konsumen, Mandar Maju, Bandung, 2000, hlm. 33.

${ }^{40}$ Susanti Adi Nugroho, Proses Penyelesaian Sengketa Konsumen Ditinjau Dari Hukum Acara Serta Kendala Implementasinya, Kencana Prenada Media Group, Jakarta, 2008, hlm. 3.

${ }^{41}$ Yusuf Sofie, Kapita Selekta Hukum Perlindungan Konsumen di Indonesia, Ghalia Indonesia, Jakarta, 2007, hlm. 17.

${ }^{42}$ Happy Susanto, Hak-Hak Konsumen Jika Dirugikan, Visimedia, Jakarta, 2008, hlm. 39.
} 


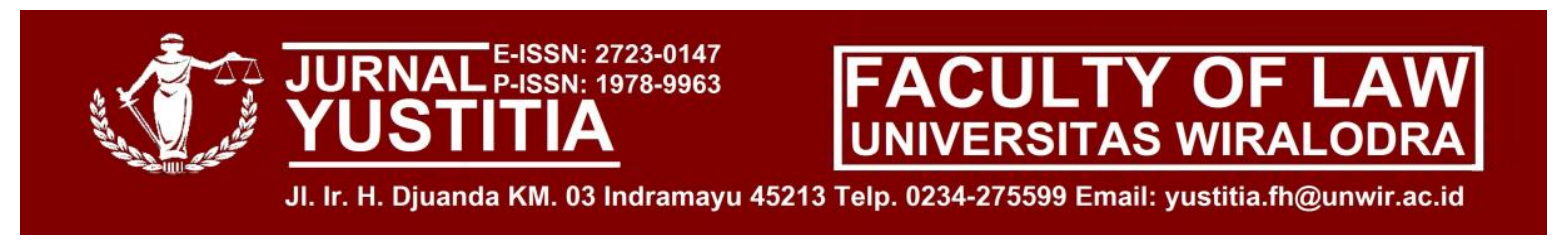

merupakan suatu hal yang penting dan mendesak, untuk segera dicari solusinya, mengingat sedemikian kompleksnya permasalahan yang menyangkut perlindungan konsumen di Indonesia lebih-lebih menyongsong era perdagangan bebas.

Secara value, Karena posisi konsumen yang lemah maka ia harus dilindungi oleh hukum. Salah satu sifat, sekaligus tujuan hukum itu adalah memberikan perlindungan (pengayoman) kepada masyarakat. Undang-Undang Nomor 8 Tahun 1999 tentang Perlindungan Konsumen merupakan seperangkat aturan hukum untuk melindungi konsumen. Dalam Pasal 1 angka 1 Undang-Undang Nomor 8 Tahun 1999 tentang Perlindungan Konsumen Yang dimaksud Perlindungan Konsumen adalah :" Perlindungan konsumen adalah segala upaya yang menjamin adanya kepastian hukum untuk memberi perlindungan kepada konsumen ".

Mengacu pada pasal 1 ayat 1 Undang-Undang No. 8 Tahun 1999 tentang perlindungan konsumen, Kata segala upaya adalah menyiratkan bahwa, secara utility perlindungan konsumen bertujuan untuk membentengi tindakan sewenang-wenangan dan agar pihak pelaku usaha memberikan hak-hak yang dimiliki oleh konsumen sebagaimana mestinya. Agar segala upaya tersebut berjalan efektif, ukurannya secara kualitatif ditentukan dalam undang-undang perlindungan konsumen dan undang-undang lainnya juga dimaksudkan dan masih berlaku untuk memberikan perlindungan terhadap kepentingan konsumen, baik dalam hukum privat (perdata) maupun dalam bidang hukum public (hukum pidana maupun hukum administrasi negara).

Secara efficiency, piranti hukum yang melindungi konsumen tidak dimaksudkan untuk mematikan usaha para pelaku usaha, tetapi justru sebaliknya perlindungan konsumen dapat mendorong lahirnya perusahaan yang tangguh dalam mengadapai persaingan melalui penyediaan barangdan/atau jasa yang berkualitas. Disamping itu, Undang-Undang Perlindungan Konsumen ini dalam pelaksanaannya tetap memberikan perhatian khusus kepada pelaku usaha kecil dan menengah. Hal ini dilakukan melalui upaya pembinaan dan penerapan sanksi atas pelanggaranya.

Undang-Undang Perlindungan Konsumen ini dirumuskan dengan mengacu pada filosofi pembangunan nasional termasuk pembangunan hukum yang memberikan perlindungan terhadap konsumen adalah dalam rangka membangun manusia Indonesia seutuhnya yang berladaskan pada falsafah kenegaraan Republik Indonesia yaitu dasar negara Pancasila dan konstitusi negaraUndang-Undang Dasar 1945. 


\section{PENUTUP}

\section{A. Simpulan}

Hukum sebagai Sistem Alokasi yang disampaikan oleh Friedman menjadi suatu keniscayaan yang makin mendekatkan orang pada suatu teorema klasik bahwa hukum bisa menyejahterakan. Hukum perlindungan konsumen adalah keseluruhan asas-asas dan kaidah-kaidah hukum yang mengatur hubungan dan masalah antara berbagai pihak satu sama lain berkaitan dengan barang atau jasa konsumen di dalam pergaulan hidup. Dengan tujuan adalah memberi perlindungan kepada konsumen agar terhindar dari halhal yang dapat menimbulkan kerugian dalam penggunaan barang dan/atau manfaat jasa.

\section{B. Saran}

Konsumen menjadi objek aktivitas bisnis untuk meraup keuntungan yang sebesar-besarnya oleh pelaku usaha melalui kiat promosi, cara penjualan, serta penerapan perjanjian standar yang merugikan konsumen. Faktor utama yang menjadi kelemahan konsumen adalah tingkat kesadaran konsumen akan haknya masih rendah. Hal ini terutama disebabkan oleh rendahnya pendidikan konsumen. Pemerintah melalui instansi-instansi terkait perlu melakukan upaya yang terus menerus untuk memberdayakan masyarakat dengan memberikan pemahaman dan perlindungan kepada konsumen

\section{DAFTAR PUSTAKA}

\section{A. Buku :}

Abdoel Djamali, Pengantar Ilmu Hukum Indonesia, Raja Grafindo, Jakarta, 2006,

Achmad Ali, Menguak Takbir Hukum (Suatu Kajian Filosofis dan Sosiologis), Cetakan Kedua, PT. Toko Gunung Agung Tbk, Jakarta, 2002.

Achmad Ali, Menjelajahi Kajian Empiris Terhadap Hukum, Yarsif Watampone, Jakarta, 1988

Adrian Sutedi, Tanggung Jawab Produk Dalam Hukum Perlindungan Konsumen, Ghalia Indonesia, Bogor 2006 
Ahmadi Miru dan Sutarman Yodo, 2008, Hukum Perlindungan Konsumen, PT. Raja Grafindo Persada, Jakarta

Celina Tri Siwi Kristiyanti, Hukum Perlindungan Konsumen, Sinar Grafika, Jakarta, 2009

Edmond Cahn, "Law in Consumer Perspective, "University of Pennyvania Law review, No.112 (1963)

Happy Susanto, Hak-Hak Konsumen Jika Dirugikan, Visimedia, Jakarta, 2008

Husni Syawali \& Neni Sri Imaniyati, Hukum Perlindungan Konsumen, Mandar Maju, Bandung, 2000

Hondius, “Konsumentenrecht, “1976, dalam Mariam Darus Badrulzaman, Perlindungan terhadap Konsumen dilihat dari Sudut Perjanjian Baku (Standar), dalam BPHN, Siposium Aspek-Aspek Hukum Perlindungan Konsumen, Binacipta, Bandung, 1986

IOCU, Gerakan dan Langkah yayasan Lembaga Konsumen, Gunung Agung, Jakarta, 1982

Lawrence M. Friedman, 2001, Hukum Amerika: Sebuah Pengantar (American Law: An Introduction), Penerjemah oleh Wishnu Basuki, PT. Tatanusa, Jakarta

Lawrence M. Friedman dalam bukunya The Legal System: A Sociology Science Perspective, dalam Soerjono Soekanto, et. all, 1986, Kriminologi Suatu Pengantar, Jakarta, Ghalia Indonesia

M.J Leder, Consumer Law (plymounth; Macdonald and Evans), 1980

Purnadi Purbacaraka dan Soerjono Soekanto, Perihal Kaidah Hukum, Citra Aditya Bakti, 1993, Bandung,

R. Lowe, Comercial Law, ed6 (London; Sweet and Maxwell, 1983)

Richard A Posner, Economic Analysis of Law, Edisi Keempat, Little Brown and Company, 1992

Romli Atmasasmita, Teori Hukum Intergratif (Rekontruksi Terhadap Teori Hukum Pembangunan dan Teori Hukum Progresif, Genta Publishing, Yogyakarta, 2012

Satjipto Rahardjo, Ilmu Hukum, PT. Citra Aditya Bakti, Bandung, 1991

Shidarta, Hukum Perlindungan Konsumen Indonesia, Edisi Revisi, PT Grasindo, Jakarta, 2006 


\section{IIRNAISEN: 2723-0147 \\ JOWNAL Lassers \\ YUSTITIA

JI. Ir. H. Djuanda KM. 03 Indramayu 45213 Telp. 0234-275599 Email: yustitia.fh@unwir.ac.id

Sudikno Mertokusumo, Penemuan Hukum: Suatu Pengantar, Liberty, Jakarta, 1996

Susanti Adi Nugroho, Proses Penyelesaian Sengketa Konsumen Ditinjau Dari Hukum Acara Serta Kendala Implementasinya, Kencana Prenada Media Group, Jakarta, 2008

Yusuf Sofie, Pelaku Usaha, Konsumen dan Tindak Korporasi, Ghalia Indonesia, Jakarta, 2002

Yusuf Sofie, Kapita Selekta Hukum Perlindungan Konsumen di Indonesia, Ghalia Indonesia, Jakarta, 2007

\section{B. Peraturan Perundang-Undangan}

Undang-Undang No 8 Tahun 1999 tentang Perlindungan Konsumen 